Prepared in cooperation with New York State Department of Environmental Conservation

\title{
Hydrogeology of the Ramapo River-Woodbury Creek Valley-Fill Aquifer System and Adjacent Areas in Eastern Orange County, New York
}

Scientific Investigations Report 2014-5156

U.S. Department of the Interior

U.S. Geological Survey 
Cover. Ramapo River valley, looking north from Arden Road, Arden, New York. 


\section{Hydrogeology of the Ramapo River- Woodbury Creek Valley-Fill Aquifer System and Adjacent Areas in Eastern Orange County, New York}

By Paul M. Heisig

Prepared in cooperation with the

New York State Department of Environmental Conservation

Scientific Investigations Report 2014-5156 


\title{
U.S. Department of the Interior SALLY JEWELL, Secretary
}

\section{U.S. Geological Survey Suzette M. Kimball, Acting Director}

\author{
U.S. Geological Survey, Reston, Virginia: 2015
}

For more information on the USGS - the Federal source for science about the Earth, its natural and living resources, natural hazards, and the environment, visit http://www.usgs.gov or call 1-888-ASK-USGS.

For an overview of USGS information products, including maps, imagery, and publications, visit http://www.usgs.gov/pubprod

To order this and other USGS information products, visit http://store.usgs.gov

Any use of trade, firm, or product names is for descriptive purposes only and does not imply endorsement by the U.S. Government.

Although this information product, for the most part, is in the public domain, it also may contain copyrighted materials as noted in the text. Permission to reproduce copyrighted items must be secured from the copyright owner.

Suggested citation:

Heisig, P.M., 2015, Hydrogeology of the Ramapo River-Woodbury Creek valley-fill aquifer system and adjacent areas in eastern Orange County, New York: U.S. Geological Survey Scientific Investigations Report 2014-5156, 23 p., 1 pl., http://dx.doi.org/10.3133/sir20145156.

ISSN 2328-0328 (online) 


\section{Acknowledgments}

The author expresses sincere thanks to those landowners, businesses, and institutions that granted access for horizontal-to-vertical (H/V) passive seismic surveys. Bill McClennan, Water and Wastewater Treatment Superintendent, Town of Woodbury, and John Karl, Superintendent of Village of Harriman Department of Public Works, shared local knowledge, well information, and also facilitated site access for seismic surveys. Steven Gagnon, Senior Public Health Engineer at the Orange County Department of Health, provided data for public-supply wells. David Church, Commissioner, and Kelly Dobbins, Orange County Planning Department, provided information and support in the early stages of the project. Thanks are extended to Scott Stanford, New Jersey Geological Survey, and Allan Randall, U.S. Geological Survey, for insightful reviews and follow-up discussions. 



\section{Contents}

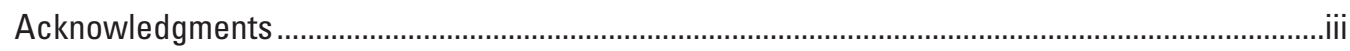

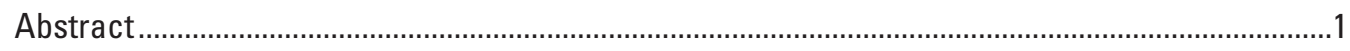

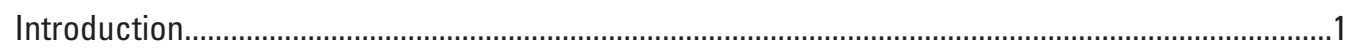

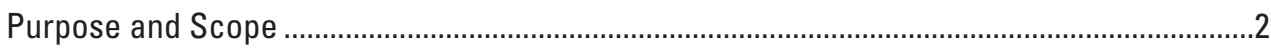

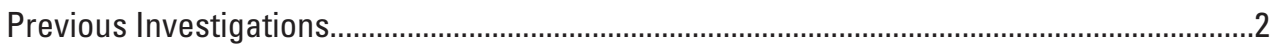

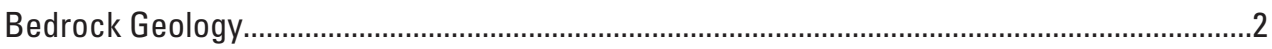

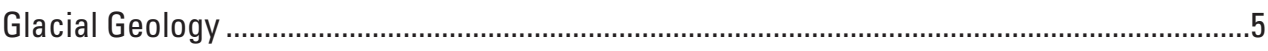

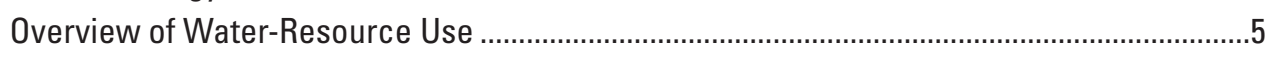

Data Sources and Methods ..............................................................................................

Hydrogeology of the Ramapo River-Woodbury Creek Valley-Fill Aquifer System ..............................7

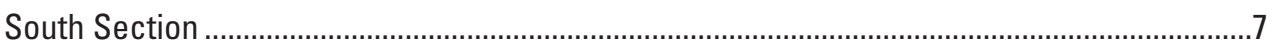

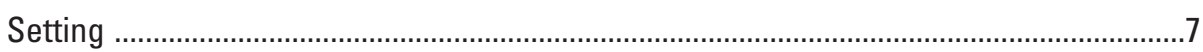

Valley-Fill Deposits and Water-Resource Potential ........................................................

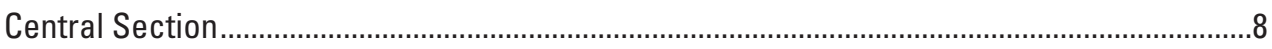

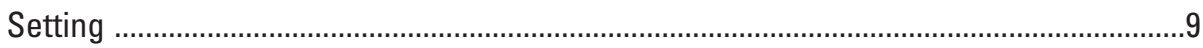

Valley-Fill Deposits and Water-Resource Potential ..........................................................

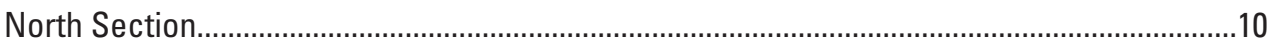



Valley-Fill Deposits and Water-Resource Potential .........................................................10

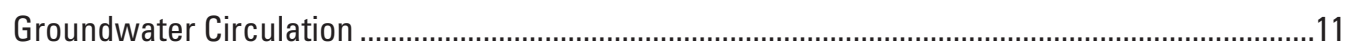

Water-Resource Considerations for the Valley-Fill Aquifer System ..............................................12

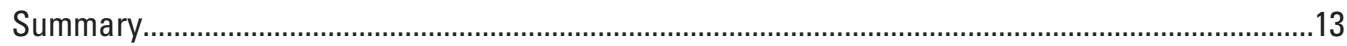

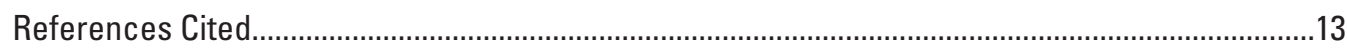

Appendix 1. Well Data for the Ramapo River-Woodbury Creek Valley and Adjacent Uplands, Eastern Orange County, New York (http://dx.doi.org/10.3133/sir20145156)........................22

Appendix 2. North-south longitudinal section along Ramapo River-Woodbury Creek valleys showing elevations of flood plains, terraces, and other valley-bottom glacial features...23

\section{Plate}

1. Hydrogeology of the Ramapo River-Woodbury Creek valley-fill aquifer system and adjacent areas in eastern Orange County, New York (http://dx.doi.org/10.3133/sir20145156)

\section{Figures}

1A. Map showing topography, political boundaries, major roads, and hydrography of the Ramapo River-Woodbury Creek study area in eastern Orange County, New York

1B. Map showing generalized bedrock geology, mapped and inferred faults, and lineaments identified from light detection and ranging (lidar) imagery of the Ramapo River-Woodbury Creek study area in eastern Orange County, New York.

2. Map showing the south, central, and north sections of the study area, the stratified-drift aquifer extent, aquifer areas of thick (10 feet or greater) saturated sand and gravel deposits, and the extent of thick till, Orange County, New York 
3. Hydrogeologic section $A-A^{\prime}$ at Arden, Orange County, New York.................................16

4. Hydrogeologic section $B-B^{\prime}$ at Harriman, Orange County, New York ...........................18

5. Hydrogeologic section $C-C^{\prime}$ at Woodbury, Orange County, New York..........................19

6. Hydrogeologic section $D-D^{\prime}$ at Mountainville, Orange County, New York ......................20

\section{Conversion Factors}

\begin{tabular}{lcl}
\hline Multiply & By & To obtain \\
\hline foot $(\mathrm{ft})$ & Length & \\
mile $(\mathrm{mi})$ & 0.3048 & meter $(\mathrm{m})$ \\
\hline & 1.609 & kilometer $(\mathrm{km})$ \\
\hline foot per minute $(\mathrm{ft} / \mathrm{min})$ & Flow rate & \\
foot per day $(\mathrm{ft} / \mathrm{d})$ & 0.3048 & meter per minute $(\mathrm{m} / \mathrm{min})$ \\
cubic foot per second $\left(\mathrm{ft}^{3} / \mathrm{s}\right)$ & 0.3048 & meter per day $(\mathrm{m} / \mathrm{d})$ \\
gallon per minute $(\mathrm{gal} / \mathrm{min})$ & 0.02832 & cubic meter per second $\left(\mathrm{m}^{3} / \mathrm{s}\right)$ \\
\hline & 0.06309 & liter per second $(\mathrm{L} / \mathrm{s})$ \\
\hline foot per day $(\mathrm{ft} / \mathrm{d})$ & Hydraulic conductivity & \\
\hline & 0.3048 & meter per day $(\mathrm{m} / \mathrm{d})$ \\
\hline foot per mile $(\mathrm{ft} / \mathrm{mi})$ & Hydraulic gradient & \\
\hline
\end{tabular}

\section{Datum}

Vertical coordinate information is referenced to the North American Vertical Datum of 1988 (NAVD 88).

Horizontal coordinate information is referenced to the North American Datum of 1983 (NAD 83).

Elevation, as used in this report, refers to distance above the vertical datum.

\section{Abbreviations}

H/V horizontal-to-vertical

lidar light detection and ranging

NWIS National Water Information System

NYSDEC New York State Department of Environmental Conservation

USGS U.S. Geological Survey 


\title{
Hydrogeology of the Ramapo River-Woodbury Creek Valley-Fill Aquifer System and Adjacent Areas in Eastern Orange County, New York
}

\author{
By Paul M. Heisig
}

\section{Abstract}

The hydrogeology of the valley-fill aquifer system and surrounding watershed areas was investigated within a 23-mile long, fault-controlled valley in eastern Orange County, New York. Glacial deposits form a divide within the valley that is drained to the north by Woodbury Creek and is drained to the south by the Ramapo River. Surficial geology, extent and saturated thickness of sand and gravel aquifers, extent of confining units, bedrock-surface elevation beneath valleys, major lineaments, and the locations of wells for which records are available were delineated on an interactive map.

Currently (2013), groundwater is the primary source of water supply in the study area. Several public water-supply systems withdraw groundwater from production wells in valley areas; elsewhere, domestic wells are used for water supply. Community-supply wells tap both sand and gravel and fractured bedrock aquifers; most domestic wells tap fracturedbedrock aquifers.

Thick, saturated sand and gravel deposits are limited in areal extent but form several localized, productive aquifer zones within the valley-fill sediments. Hydraulic interconnection among these zones is largely untested. Finegrained lacustrine deposits form extensive confining units above some aquifer material. Till deposits that extend into valleys also confine sand and gravel or bedrock aquifers. The study area was divided into three sections - south, central, and north.

The south section of the study area, from Harriman south to the Rockland County and New Jersey borders, includes the south-draining valleys of the Ramapo River and Summit Brook. South of the wide valley area at Harriman, the valleys are narrow and the valley-fill aquifers are largely untested; the most favorable aquifer conditions are likely at Arden and where major tributary streams enter the valley, between Southfields and We-Wah Lake. At Harriman, the Ramapo River valley fill has water-resource potential from ice-contact sand and gravel deposits.

The central section of the study area encompasses the headwater drainage area of the Ramapo River, from Harriman to Monroe and Kiryas Joel. The valley-fill aquifer material is generally thin, mostly unconfined, and underlain by glacial till. Shallow production wells tap parts of this aquifer, and appear most productive when sited near surface-water bodies. Production wells in the section are frequently completed in the underlying bedrock.

The north section of the study area encompasses the watershed of north-draining Woodbury Creek to just north of its confluence with Moodna Creek. The width of the valley bottom and type of valley-fill deposits vary considerably within the valley. The section likely has the greatest waterresource potential - both confined and unconfined aquifers are present and the village of Woodbury and town of Cornwall draw water supply from production wells. Aquifer potential appears most promising north of Central Valley, but several areas in this section are largely untested.

Valley-fill aquifers are modest resources within the area, as indicated by the common practice of completing supply wells in the underlying bedrock rather than the overlying glacial deposits. Groundwater turbidity problems curtail use of the resource. However, additional groundwater resources have been identified by test drilling, and there are remaining untested areas. New groundwater supplies that stress localized aquifer areas will alter the groundwater flow system. Considerations include potential water-quality degradation from nearby land use(s) and, where withdrawals induce infiltration of surface-water, balancing withdrawals with flow requirements for downstream users or for maintenance of stream ecological health.

\section{Introduction}

This study is a continuation of a series of hydrogeologic appraisals that have been conducted since 1980 in cooperation with the New York State Department of Environmental Conservation (NYSDEC) through the Aquifer Mapping Program. These reports provide a foundation for wellhead protection programs, water-resource management and planning decisions, and groundwater remediation in upstate New York. 
In 2011, the U.S. Geological Survey (USGS), in cooperation with the NYSDEC, began an appraisal of the valley-fill aquifer system in a 23 -mile (mi) reach of the Ramapo River-Woodbury Creek valley and adjacent areas in eastern Orange County, New York (fig. 1). The county is undergoing rapid population growth - between 2000 and 2010 , population increased by 9.2 percent in the county overall and by 20 percent or more in the Towns of Monroe and Woodbury (Orange County Department of Planning, 2014). Thus, an understanding of water-resource potential and limitations is a priority for the NYSDEC.

\section{Purpose and Scope}

This report summarizes the hydrogeology of the valleyfill aquifer system in the 23-mi long Ramapo River-Woodbury Creek valley and in the western spur of the upper Ramapo River valley in eastern Orange County, N.Y. (figs. $1 A$ and $B$ ). The area encompasses part or all of the towns of Tuxedo, Monroe, Woodbury, and Cornwall, and the villages of Tuxedo Park, Monroe, Harriman, Kiryas Joel, and Woodbury. An interactive map plate was constructed with several layers of information:

- Extent of the valley-fill aquifer system

- Surficial geology

- Thickness of saturated sand and gravel

- Extent of subsurface lacustrine confining units

- Elevation of the bedrock surface within the valley

- Major lineaments, identified from light detecting and ranging (lidar) imagery

- Locations of geologic sections and links to accompanying illustrations

- Well and seismic-survey locations

- Locations of former meltwater channels

- Base maps

- High-resolution, shaded lidar imagery of land surface

- 1:24,000 scale topographic maps

Figures depict the study area, hydrogeologic sections, and favorable water-resource areas within the Ramapo RiverWoodbury Creek valley. Accompanying text summarizes the bedrock and glacial geology, the current (2013) use of water resources, and the hydrogeologic framework of glacial deposits within the valley areas. A table of well data is included in appendix 1.

\section{Previous Investigations}

Surficial geology (Pleistocene glacial and post-glacial Holocene deposits) has been mapped several times in the study area: (1) unpublished maps of surficial geology were prepared for the construction of the New York State Thruway (Interstate 87 , fig. $1 A$; on file at USGS, Troy, N.Y.), (2) a map of the surficial geology of Orange County by Frimpter (1972), (3) SSURGO soils datasets, which describes soil parent material and characterizes the uppermost 5 to 10 feet (ft) of overburden (U.S. Department of Agriculture, 2011, derived from the soil survey of Orange County, U.S. Department of Agriculture, 1981), and (4) a regional map (1:250,000 scale) of surficial geology compiled by Cadwell (1989). Stanford $(1992,2004)$ mapped the surficial geology of parts of the Sloatsburg and Ramsey quadrangles (1:24,000 scale) immediately south of the study area in New Jersey.

Existing groundwater supplies in the area were developed on the basis of many local exploratory investigations and wellfield evaluations performed by private consultants. A notable, areally extensive early test-well drilling program for the town of Cornwall was performed by Hazen and Sawyer (1963).

Two county-wide efforts (Frimpter, 1970, 1972; Leggette, Brashears, and Graham, Inc.,1994) represent substantial work in hydrogeologic characterization (aquifer delineation) and water-resource assessment within the study area. Frimpter (1972) classified aquifer conditions throughout the valley area and assessed the water-resource potential of four aquifer subareas. Leggette, Brashears and Graham, Inc. (1994) compiled and synthesized well, aquifer, and water-use data, by town, from local consultants; this study used the classification scheme of Frimpter (1972) and the updated well and water-use datasets to describe groundwater resources of the county.

\section{Bedrock Geology}

Previous studies during the 1960s and 1970s mapped a variety of bedrock types in the study area (Fisher and others, 1970; Jaffee and Jaffee, 1973; Dodd,1965) and bedrock mapping in the study area is ongoing (Gates and Valentino, 2000; Gates and others, 2001; Valentino and others, 2004; McNamara and others, 2008). Bedrock in the southern and eastern parts of the study area consists of resistant Precambrian age metamorphic rocks (mostly gneiss) of the Hudson Highlands region. Bedrock in the northwestern part of the study area consists of folded and faulted clastic and carbonate sedimentary rocks of Cambrian through Devonian age, which lie within the Hudson-Mohawk Lowlands or Great Valley physiographic region (fig. $1 B$; Fisher and others, 1970; Isachsen and others, 2000). The sedimentary rocks are subdivided into predominantly clastic and carbonate areas in fig. $1 B$. The clastic rocks include resistant sandstones and conglomerates that underlie high-elevation featuresSchunemunk Mountain (the Schunemunk Conglomerate 


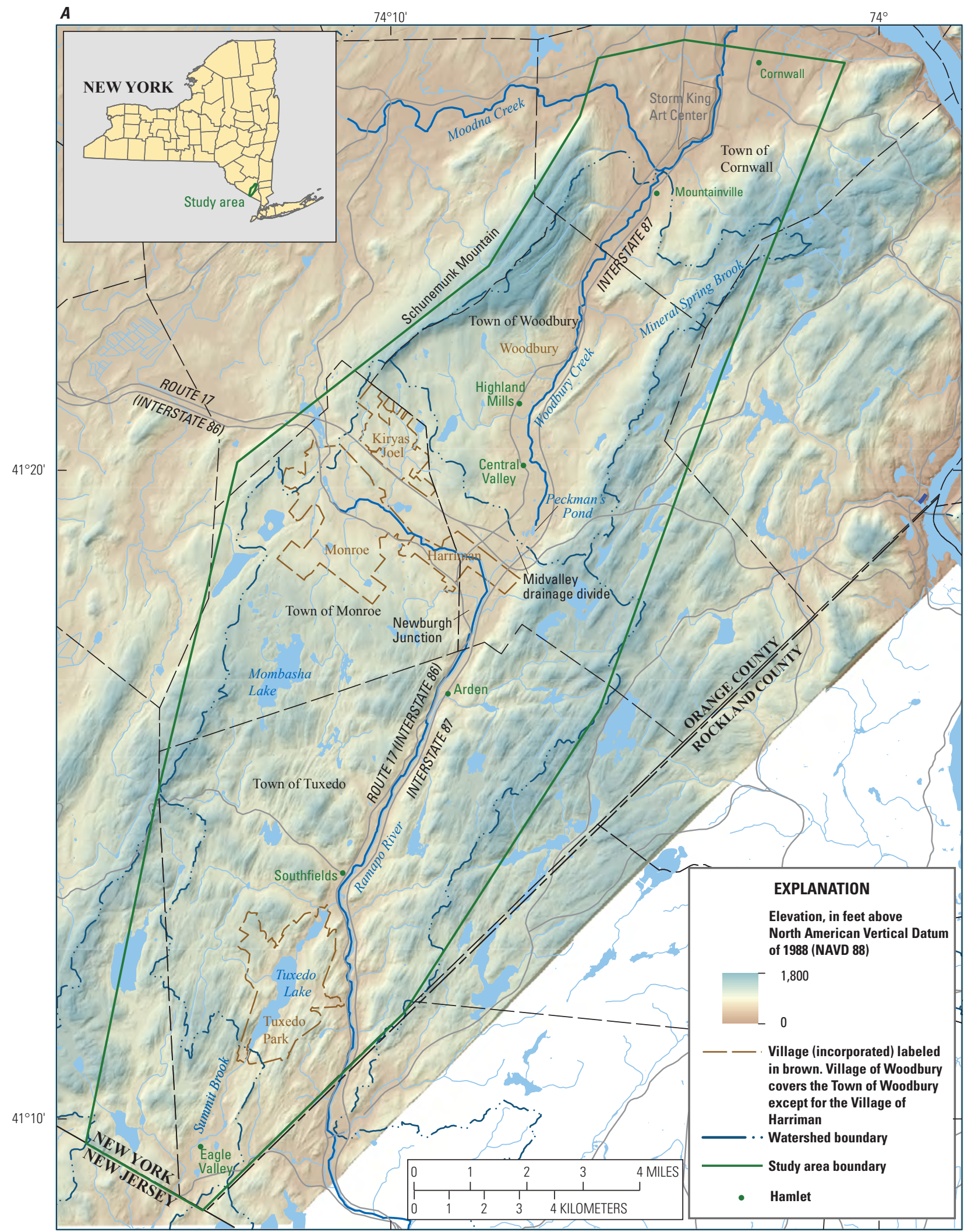

Base from Orange County GIS Division, 10-foot digital elevation model, 2004, NAVD 88 Universal Transverse Mercator projection, custom, NAD 83

Figure 1A. Topography, political boundaries, major roads, and hydrography of the Ramapo River-Woodbury Creek study area in eastern Orange County, New York. Note: Village of Woodbury boundary is coincident with Town of Woodbury boundary except for the Village of Harriman area that is within the Town of Woodbury. 


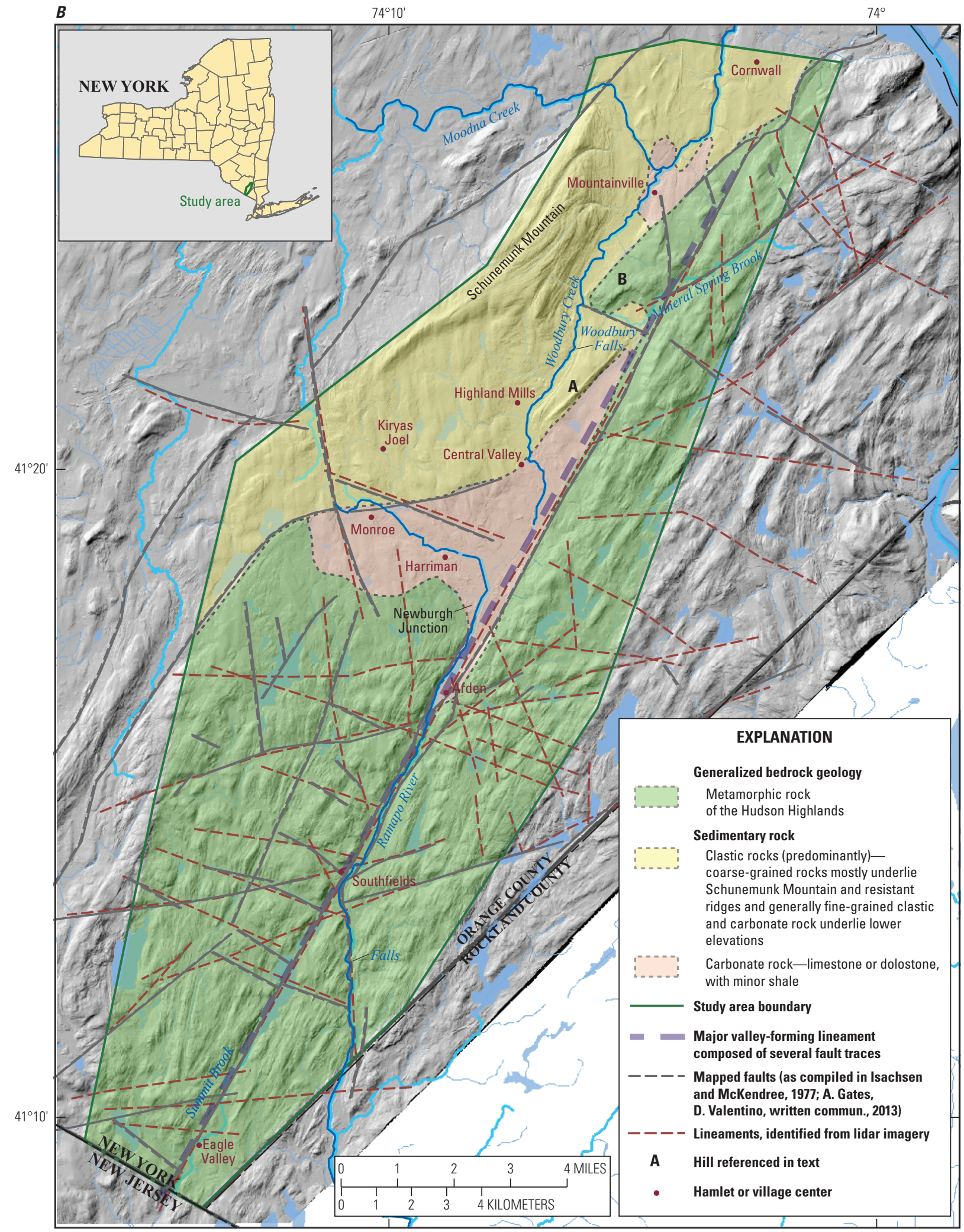

Base from Orange County GIS Division, 10-foot digital elevation model, 2004, NAVD 88 Universal Transverse Mercator projection, custom, NAD 83

Figure 1B. Generalized bedrock geology, mapped and inferred faults, and lineaments identified from light detection and ranging (lidar) imagery of the Ramapo River-Woodbury Creek study area in eastern Orange County, New York. 
[as noted in Rickard, 1975] and the Bellvale Formation) and a low, straight ridge (hill A, fig. $1 B$ ) east of Schunemunk Mountain composed of the Schawangunk Formation (Epstein, 1993). Fine-grained, less resistant clastic rocks (for example, the Martinsburg Formation and the Esopus Shale) or faulted bedrock units generally underlie low-elevation areas (most of the Woodbury Creek valley and areas to the north). The carbonate rock is limestone and dolostone (with minor shale and chert) of the Cambrian-Ordovician age Wappinger Group, which underlies valley areas in the central part of the study area and locally in the southern and northern parts of the study area.

Bedrock is faulted and fractured in the study area (fig. $1 B$ ), and most of the valleys are coincident with mapped or inferred faults or with linear topographic features (lineaments). A major linear feature that extends southwestnortheast along the length of the study area (fig. $1 B$ ) is formed by several fault segments that underlie parts of the valleys of Summit Brook, the Ramapo River, Woodbury Creek, and Mineral Spring Brook. This major linear feature is herein referred to as the main fault valley. Both the southern reach of the Ramapo River valley and the northern reach of Woodbury Creek valley depart from the main fault valley and follow other faults. In faulted valley areas underlain by sedimentary rock, drillers' well logs commonly describe intervals of rotten, deeply weathered bedrock or clay. A quarry in the faulted Woodbury Creek valley area also exposes pervasively fractured rock. The carbonate rocks have been modified by karst development (dissolution and creation of cavities or fissures) in addition to modifications by faulting and deep weathering.

\section{Glacial Geology}

The glacial-drift deposits of the study area (Pleistocene age) consist largely of thin or thick till over bedrock in upland areas and stratified deposits in the valleys (fig. 2). Thick till is most common on upper topographic slopes that faced advancing ice or on lower lee-side slopes of large topographic features, such as Schunemunk Mountain.

Stratified-drift deposits provide evidence of the sequence of deglaciation in the area. Deposits in the Ramapo River valley as far north as Arden indicate that meltwaters drained southward, the meltwaters were sufficiently impounded or impeded by glacial-drift dams to create a shallow proglacial lake in which lacustrine sand was deposited. A pause in the ice retreat at Arden resulted in the deposition of thick sand and gravel (an outwash head), whose upper surface is well above the present-day flood plain. Outwash prograded downvalley over the lacustrine deposits. Ice-contact deposits along valley walls east of Harriman and in the upper Woodbury Creek valley indicate that meltwater drained within or adjacent to the ice from north to south across the present-day midvalley drainage divide (figure $1 B$ ). Ice retreat north from Arden resulted in the impoundment of meltwater behind, and partial incision of, the sediment build up at Arden. The partial incision of the deposits at Arden or of a downvalley plug of glacial drift controlled the level of a proglacial lake north of Arden that occupied the broad valley area at Harriman. Meltwater from the west-to-east reach of the Ramapo River valley northwest of Harriman was limited and discharged into the lake at Harriman.

The proglacial lake at Harriman progressively expanded northward as the ice retreated. The elevation of a kame delta at Highland Mills marks a lake level of 545-550 ft above North American Vertical Datum 1988 (NAVD 88), which indicates that the proglacial lake was continuous southward across the present-day midvalley divide (at about $526 \mathrm{ft}$ ) to the Arden area. Substantial valley-fill deposits in the Arden area, with terrace levels around 545-555 ft, may have provided at least a temporary control on the lake level. The lake level likely declined as the valley-fill deposits at Arden or a downvalley control were incised. Eventually, the present-day midvalley divide became the outlet and control for the lake in the Woodbury Creek valley. A pause in ice retreat in the Highland Mills-Woodbury area resulted in the greatest accumulation of sand and gravel in the Woodbury Creek valley, adjacent to the ice tongue. North of this area to Mountainville, sand and gravel deposition was mostly limited to subglacial meltwater channels or lacustrine fans, over which fine-grained lacustrine deposits or till were later deposited. Further ice retreat initiated eastward drainage of water impounded west of Schunemunk Mountain and in the Woodbury Creek valley along pathways between the ice margin and the north edges of Schunemunk Mountain and the Hudson Highlands into a lake in the Hudson valley with a level of less than $400 \mathrm{ft}$ (Connally and Sirkin, 1967; Connally and others, 1989). As lake level in the Woodbury Creek valley dropped to the new base level, northward drainage in Woodbury Creek valley was initiated and the midvalley drainage divide was established. The deposition of sand and gravel ceased and fine-grained lacustrine sediments were deposited in the Woodbury Creek valley between Mineral Spring Brook and Mountainville. Lake drainage from the lowlands west of the study area (Connally and Sirkin, 1967; Connally and others, 1989) through the Moodna Creek valley at the north edge of Schunemunk Mountain both scoured the till and deposited localized sand and gravel. Areas of ice-contact sand and gravel were deposited north of Moodna Creek as ice retreat continued. Subsequent draining of the lakes in the Hudson River valley and the Woodbury Creek valley initiated downcutting of the glacial deposits and deposition of Holocene alluvial deposits (flood-plain alluvium and alluvial fans).

\section{Overview of Water-Resource Use}

Groundwater is the source for most water supplies in the study area. Community groundwater supplies from production wells serve about 41,000 people in Kiryas Joel village, Harriman village, and the town and village of Woodbury, 


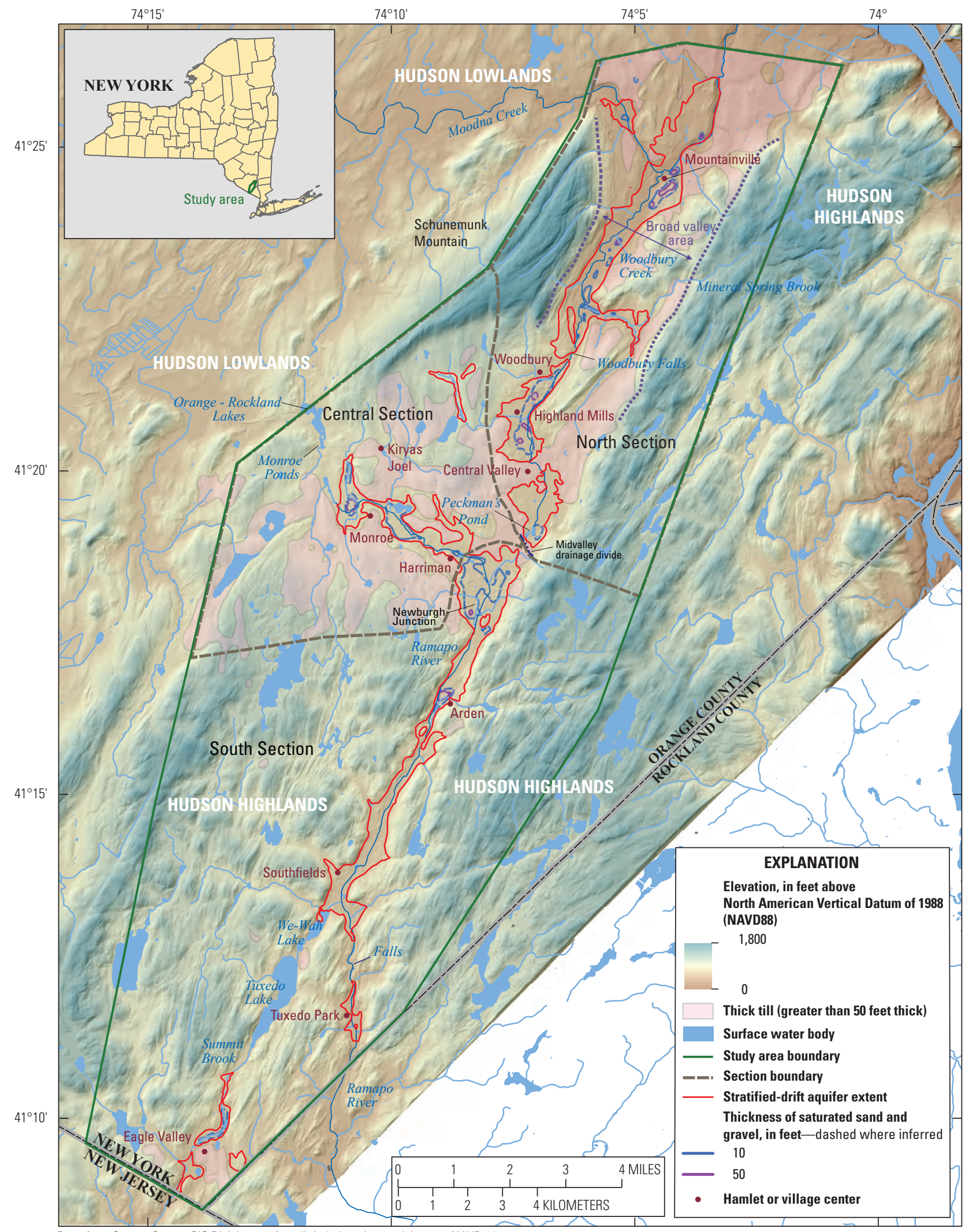

Base from Orange County GIS Division, 10-foot digital elevation model, 2004, NAVD 88

Universal Transverse Mercator projection, custom, NAD 83

Figure 2. The south, central, and north sections of the study area, the stratified-drift aquifer extent, aquifer areas of thick (10 feet or greater) saturated sand and gravel deposits, and the extent of thick till, Orange County, New York. 
whereas community surface-water supplies serve about 11,500 people in Monroe village and town (from Mombasha Lake) and Tuxedo Park village (from Tuxedo Lake) (U.S. Environmental Protection Agency, [n.d.]). Groundwater is the sole source for all individual domestic supplies outside of the water districts served by the community water systems.

Groundwater is withdrawn from both sand and gravel (glacial) and fractured-bedrock aquifers. The highest well yields are obtained from production wells completed with screens in sand and gravel - the highest sustainable yields from these wells are typically about $350-400$ gallons per minute $(\mathrm{gal} / \mathrm{min})$ based on a review of records on file at the Orange County Department of Health. However, thick, saturated sand and gravel aquifers are limited in extentonly about 7 percent of wells in appendix 1 are completed in sand and gravel. The bedrock aquifer is widely used for domestic groundwater supply, especially in upland areas. Community water supplies commonly use the sedimentary bedrock aquifers that underlie valley areas north of Arden (fig. 1); sustainable yields from these production wells tapping bedrock are on the order of 100-200 gal $/ \mathrm{min}$.

High turbidity is a common problem in bedrock production wells; clays in deeply weathered zones, which are likely related to faulting or to lithologies susceptible to weathering (carbonate, arkosic sandstone, and micaceous gneiss) or clays present as infillings in karst features in carbonate rock, are suspended by the rapid groundwater flow associated with pumping. Furthermore, accumulation of clay on screens and pumps can decrease well yields over time (D. Lindsey, Riddick Associates.; T. Cusack, Leggette, Brashears, and Graham, Inc.; oral commun., 2012).

\section{Data Sources and Methods}

Surficial geology, subsurface deposits, and aquifer boundaries were based on well-log data, SSURGO digital soilsurvey database (U.S. Department of Agriculture, 2011), lidar imagery, and previously compiled geologic maps. The aquifer boundary or "aquifer extent" is the extent of contiguous stratified-drift deposits within valleys, including largely unsaturated deposits on adjacent hillside areas.

Sources of well and test-boring records include previous USGS groundwater studies (especially Frimpter, 1970; and the USGS National Water Information System [NWIS]; U.S. Geological Survey, 2001), the NYSDEC Water Well Drillers Registration Program, the New York State Thruway Authority, and New York State Department of Transportation. All records collected for this study are compiled in appendix 1 and were entered into the USGS NWIS database (U.S. Geological Survey, 2001), which is accessible at http://waterdata.usgs. gov/nwis/.

Passive seismic, or horizontal-to-vertical (H/V) ambientnoise seismic surveys, were carried out at 33 sites to estimate the thickness of sediments overlying bedrock. The H/V passive seismic method uses a single broadband three-component
( $\mathrm{x}, \mathrm{y}$, and $\mathrm{z}$ directions) seismometer to record ambient seismic noise. The ratio of the averaged horizontal $(x, y)$ to vertical (z) frequency spectrum is used to determine the fundamental site resonance frequency, which can be interpreted using regression equations to estimate sediment thickness overlying bedrock (Lane and others, 2008). The most distinct H/V peaks and best estimates of sediment thickness were at sites with stratified drift over bedrock. Indistinct or absent $\mathrm{H} / \mathrm{V}$ peaks were generally indicative of till overlying bedrock with little or no stratified drift.

\section{Hydrogeology of the Ramapo River-Woodbury Creek Valley-Fill Aquifer System}

The extent of stratified drift (the valley-fill aquifer boundary) within the study area is depicted on plate 1; also shown are surficial geology, the thickness of saturated sand and gravel, the extent of confining units, major lineaments, and the elevation of the bedrock surface beneath the valleys. An overview map (fig. 2) shows the boundaries of the three sections of the study area (south, central, and north) that are discussed in the text as well as the aquifer extent, areas with thick saturated sand and gravel, and areas of thick till. The areas of thick saturated sand and gravel are conservatively delineated; isolated areas of saturated sand and gravel, particularly in the Woodbury Creek (north) section of the study area, may be more extensive than indicated. Four hydrogeologic sections illustrate the hydrogeologic framework of the valley fill.

\section{South Section}

This section extends from the midvalley drainage divide, which is northeast of Harriman, to southern boundary of the study area near the border of Orange County with Rockland County, N.Y. and Passaic County, New Jersey. (fig. 2). The south section includes the north-south reach of Ramapo River valley, its watershed, and the Summit Brook watershed.

\section{Setting}

The valleys and uplands of the south section (fig. 2) are underlain by resistant Hudson Highlands metamorphic bedrock, except where carbonate bedrock underlies the Ramapo River valley from Harriman and Newburgh Junction southward to Arden (fig. 1B, fig. 2; Jaffee and Jaffee, 1973;

A. Gates, Rutgers University, D. Valentino, State University of New York at Oswego, written commun., 2013). The Ramapo River valley, follows a major fault, is linear and narrow (generally less than 0.4-mi wide) from Newburgh Junction through Arden to just beyond Southfields (fig. 1B). South 
of Southfields, the Ramapo River turns due south across the bedrock grain to Tuxedo Park along another lineament. This valley reach is narrow, and about $1 \mathrm{mi}$ south of the southward turn, the Ramapo River flows on bedrock and over a waterfall before continuing south through Tuxedo Park and into Rockland County. The major fault valley (fig. $1 B$ ) continues to the southwest and is obstructed by till deposits that originally impounded Tuxedo Lake. These till deposits form the drainage divide between the Ramapo River and Summit Brook watersheds. Southwest of the divide, the Summit Brook valley continues southward to Eagle Valley and into New Jersey.

Till cover in upland areas is minimal, and glacial erosion has enhanced some of the lineament traces, as indicated on plate 1 and figure $1 B$. Drainage in upland areas is poor, and there are many wetlands and lakes that occupy glacially eroded depressions in the resistant bedrock or are ponded by accumulations of till.

\section{Valley-Fill Deposits and Water-Resource Potential}

Valley-fill deposits in the south section, from north to south include: (1) ice-contact sand and gravel partly covered by fine-grained lacustrine sediments in the broad valley area east of Harriman; (2) an increase in ice-contact and outwash sand and gravel at an inferred outwash head around Arden; and (3) downvalley of Arden, sandy lacustrine deposits overlain by outwash terrace remnants (appendix 2), with inferred coarser-grained valley fill where large tributaries enter the Ramapo River valley. In the southernmost reaches of the Ramapo River and Summit Brook valleys, valley-fill deposits are thin and become discontinuous (fig. 2; plate 1). For example, an isolated aquifer area is mapped in the Summit Brook valley at Eagle Valley and saturated sand and gravel thicknesses locally exceed $10 \mathrm{ft}$ (fig. 2; plate 1).

The ice-stagnation area east of Harriman is characterized by ice-contact sand and gravel deposits at land surface on its southwest and eastern borders and by isolated ice-contact hummocks across the area (fig. 2; plate 1). Impoundment of water in the area before incision of the outwash head at Arden to the present-day elevation led to the deposition of lacustrine fine-grained sand, silt, and some clay (confining units in plate 1) over low-lying ice-contact sediments and till. Subsurface hydraulic connection among the underlying icecontact deposits is likely. Valley fill is relatively thin (typically less than $80 \mathrm{ft}$ ), as indicated by well logs and by the presence of a low bedrock hillock on the eastern side of the area.

Water-resource potential is likely greatest in the ice-contact deposits along the southwest edge of the valley, as indicated by saturated thicknesses of sand and gravel that exceed $10 \mathrm{ft}$ (plate 1; fig. 2). The maximum reported yield of a sand and gravel well in this area is about $250 \mathrm{gal} / \mathrm{min}$ (Metcalf and Eddy, written commun., 1972, on file at USGS).

The outwash head at Arden formed where the valley rapidly constricts to its narrowest reach. Terraces mapped previously as undifferentiated sand and gravel or as kame sand and gravel are present as high as $60-70 \mathrm{ft}$ above the present-day river level. The valley fill at Arden changes downvalley (within a few hundred feet) from fine-grained lacustrine deposits overlying sand and gravel (fig. 3 at back of report) to all sand and gravel. The valley-fill deposits below the river level have good water-resource potential at this location, whereas the terrace deposits are mostly unsaturated (plate 1).

Between Arden and Tuxedo Park (fig. 2), Ramapo River alluvium is bounded by terrace remnants, which were identified on the basis of lidar elevation data, at heights of 10 to $60 \mathrm{ft}$ above the river (appendix 2). The terraces are commonly described as sand or sand and gravel in well logs and are mapped as outwash sand and gravel on plate 1. These deposits also are mostly unsaturated. Alluvium along the Ramapo River is graded to bedrock in the river channel north of Tuxedo Park (appendix 2), and alluvium of major tributaries is graded to the present-day flood plain. In contrast, older alluvial fan deposits with little present-day streamflow appear to be graded to the terraces.

Little subsurface data are available for the valley-fill deposits south of Arden, but a few well logs indicate that fine lacustrine sand (likely including some silt) is present with perhaps some underlying coarse-grained sediments. Glacial lakes likely formed behind sediment dams (now eroded) as indicated by the terraces (appendix 2). Valley reaches where the largest tributaries join the Ramapo River are the most likely areas to have permeable, coarse-grained deposits. The best example of this setting is the 1.5- mi long Ramapo River valley reach south from Southfields. Several lineament valleys occupied by tributary streams intersect the Ramapo River valley in this reach (fig. $1 B$; plate 1 ). Leggette, Brashears, and Graham, Inc. (1994) inventoried one well in this area (completed in sand and gravel) that reportedly yielded about $100 \mathrm{gal} / \mathrm{min}$ (see well O1564; plate 1 and appendix 1). The southern extent of contiguous aquifer material in the Ramapo River valley ends just south this reach, where the Ramapo River exits its original fault-controlled valley and flows due south along another valley (partly over bedrock) towards Tuxedo Park. A local aquifer area of limited thickness is depicted at Tuxedo Park.

South of the Ramapo River-Summit Brook drainage divide, Summit Brook crosses a small, isolated area of the stratified-drift aquifer at Eagle Valley (fig. 2; plate 1). Valleyfill deposits of sand or sand and gravel reach a maximum thickness of $50 \mathrm{ft}$ (perhaps up to $30 \mathrm{ft}$ of saturated thickness), as indicated by well logs within this area.

\section{Central Section}

The central section of the study area includes the headwater reach of the Ramapo River, which flows eastward from the village of Monroe to Harriman. This section also includes the surrounding low uplands that are characterized by substantial areas of thick till (fig. 2; plate 1). 


\section{Setting}

The central section is bounded on the north and south by resistant rock with little or no till cover - on the north by the resistant conglomerates and sandstones of Schunemunk Mountain (about $800 \mathrm{ft}$ of relief) and on the south by metamorphic rock of the Hudson Highlands (about $600 \mathrm{ft}$ of relief). The watershed divide northwest of Monroe village is only about $20 \mathrm{ft}$ higher than the headwaters of the Ramapo River. The valley, which is fault controlled (Jaffee and Jaffee, 1973; A. Gates, Rutgers University, D. Valentino, State University of New York at Oswego, written commun., 2013), is primarily underlain by carbonate rock and minor shale of the Wappinger Group (fig. 1B; fig. 4 at back of report). Most low-elevation areas adjacent to the Ramapo River are underlain by clastic and carbonate sedimentary bedrock of Cambrian-Ordovician to Devonian age. (Jaffee and Jaffee, 1973; A. Gates, Rutgers University, D. Valentino, State University of New York at Oswego, written commun., 2013). The valley is poorly developed topographically, at least partly, because it was transverse to the direction of glacial ice flow; hence, glacial erosion was minimal and deposits of till within it are generally thick. The Ramapo River exits the central section of the study area at its eastern boundary with the south section - at the broad valley area immediately east of Harriman (fig. 2).

\section{Valley-Fill Deposits and Water-Resource Potential}

Till is the thickest and most widespread glacial deposit within the central section, and commonly underlies the stratified valley-fill deposits (fig. 4 at back of report). Thick till was deposited by south-flowing ice on the lee side of Schunemunk Mountain at low elevations and across the adjacent Ramapo River valley areas. Thick till deposits also form the present-day Ramapo River-Woodbury Creek drainage divide (fig. 2). Till deposits on the lee side of Schunemunk Mountain appear to be a till shadow (Coates, 1966). Thick till also forms an apron on the south side of the east-west Ramapo River valley, which faced south-flowing ice. Witte (2011) and Stanford (1992) have described similar deposits in northern New Jersey and attribute them to pressure melting of glacial ice as it impinges on areas of higher topography.

The inputs of meltwater and sediment to this upper reach of the Ramapo River valley were small and were mostly from local ice. However, there also may have been brief periods of meltwater input from across the low divide northwest of Monroe village and, perhaps, from across the high ridge of Schunemunk Mountain. Sediment deposition in the poorly drained east-west valley reach mostly consists of thin outwash deposits around the till hills, as depicted in figure 4 and plate 1 . Well yields as high as $450 \mathrm{gal} / \mathrm{min}$ have been reported from the thin outwash adjacent to the Mountain Lakes and adjacent the Ramapo River (plate 1). Coarse-grained sediments also were deposited in the east part of the section as the meltwaters entered the proglacial lake at Harriman. These saturated, shallow sands and gravels are used for water supply by the village of Harriman, and the highest reported yield of wells completed in sand and gravel in the Harriman area is about $200 \mathrm{gal} / \mathrm{min}$.

The thickest sand and gravel deposits in the valley of the central section (about $85 \mathrm{ft}$ thick; well O1566, appendix 1) are of local extent in the village of Monroe at the west end of the section (fig. 2; plate 1). These deposits presumably are derived from the relatively limited eastward meltwater drainage (fig. 2; plate 1) over the low divide from the west. Drainage from the west is a plausible sediment source because soil maps indicate ice-contact deposits at the north end of Orange-Rockland Lakes at elevations as high as $625 \mathrm{ft}$ above NAVD 88, whereas the floor of the meltwater channel divide between OrangeRockland Lakes and the Monroe Ponds has a maximum elevation of only $606 \mathrm{ft}$.

Thinning of the ice over Schunemunk Mountain would have disconnected the leeward ice from active ice flow, and downwasting of that ice would have occurred with limited transport of sediment by meltwater beyond this area. However, some limited meltwater input from ice on the north side of Schunemunk Mountain appears plausible. Notches along the ridgeline of southern Schunemunk Mountain contain rounded cobbles in the soil, indicating possible water transport at some point during deglaciation; these ridgeline notches are paired with notches on the lee hillside and with several lakes at the bottom of the notches. The lakes are contiguous with several low-relief drainage channels about 100 to $500 \mathrm{ft}$ wide that cross the low upland area and feed into the valley (plate 1); the channels are visible in lidar imagery and are indicated, in part, by soil data (soil with alluvial parent material or those described as extremely stony [possibly washed by meltwater]).

Up to $60 \mathrm{ft}$ of stratified sediment has been reported in some low-gradient sections of these channels, consisting of thin sand and gravel beneath fine-grained sediments. The sand and gravel and underlying bedrock have previously been tapped for public supply (plate 1 for example, wells O1565-67; Leggette, Brashears, and Graham, Inc., 1987). Well yields ranged from 9 to $120 \mathrm{gal} / \mathrm{min}$. Where these channels meet the valley, sand and gravel deposits have been noted in exploratory drilling logs (plate 1 and appendix 1; wells O1554, O3501, O1482, O5257, Leggette, Brashears, and Graham, Inc., 1997; 1999), and some saturated thicknesses may be sufficient to support production wells in sand and gravel or bedrock.

Well yields in the central section are highest in valleybottom areas near the Ramapo River. Despite maximum reported test-well yields on the order of hundreds of gallons per minute, most identified sand and gravel deposits in the central section have characteristics that indicate more modest potential yields. Depths to bedrock as much as $137 \mathrm{ft}$ have been reported in areas of stratified drift, but the surficial aquifers are generally underlain by thick till (fig. 4 at back of report), which limits the discharge of groundwater from bedrock to the surficial aquifer. The saturated thickness of sand and gravel typically is less than $30 \mathrm{ft}$; aquifer width 
is generally less than $2,000 \mathrm{ft}$ and often less than $1,000 \mathrm{ft}$. Induced infiltration from the Ramapo River may augment this resource, but given the small watershed of the Ramapo River and its tributaries, induced infiltration cannot be relied on to sustain large withdrawals during extended dry periods. Bedrock wells that derive some of their yield from overlying, permeable glacial deposits are generally the most reliable sources of water supply in the area.

\section{North Section}

This section covers most of the northward-draining study area. It includes the entire 7.2-mi length of Woodbury Creek and a 2.5-mi long reach of Moodna Creek upstream and downstream from the confluence with Woodbury Creek (fig. 2).

\section{Setting}

The north section of the study area (fig. 2), drained by Woodbury and Moodna Creeks, is bounded by Schunemunk Mountain on the west side and the Hudson Highlands on the east side. Relief in the section is greater than $1,000 \mathrm{ft}$. The present-day Woodbury Creek valley is set within a broad valley ( 1.7 to $2.5 \mathrm{mi}$ in width) that is outlined in figure 2 . The north end of the section opens into the Hudson Lowlands, an area of low relief. The upper 4-mi reach of the Woodbury Creek valley is floored by alternating wide and narrow (or non-existent) flood plain areas and includes a waterfall at the northern end (fig. 2). This reach is mostly walled by relatively low-relief sedimentary rock on both sides. The lower 3-mi reach of the Woodbury Creek valley is more regular, is about 0.5 -mi wide, and is walled by the sandstones and conglomerate of Schunemunk Mountain on the west and by metamorphic Hudson Highlands rock on the east. Valleybottom areas are underlain by faulted carbonates, sandstones, and shales (figs. $1 B$, figs. 5 , and 6 at back of report). The reach of Moodna Creek within the study area traverses the Hudson Lowlands west to east, just north of Schunemunk Mountain and the Hudson Highlands. The underlying bedrock is primarily shale and siltstone with some local areas of sandstone and carbonate (fig. $1 B$, fig. 6 at back of report).

The drainage divide between the Woodbury Creek and Ramapo River watersheds in the main fault valley is coincident with low hills that are primarily composed of till, but also include some ice-contact deposits. The hills along the drainage divide have been excavated or reshaped by human activities over much of the area; comparison of lidar elevation data with an old (1935) topographic map (Monroe, New York, USGS quadrangle map, 1:24,000 scale) indicates that the low point of the divide was about $526 \mathrm{ft}$ above NAVD 88 before human alteration. From this divide, Woodbury Creek valley initially follows the main fault trace (fig. $1 B$ ) northward for a short distance, shifts to the west at Central Valley, and then continues northward parallel to the main fault trace until its confluence with Moodna Creek. The headwater section of Woodbury Creek above the falls at Woodbury is characterized by a low gradient; the elevation of the land surface drops only about $50 \mathrm{ft}$ over $3.5 \mathrm{mi}$ (fig. 2; appendix 2). Downgradient of the bedrock control at the falls, the gradient to the confluence with Moodna Creek is much higher-elevation drops by about $200 \mathrm{ft}$ over $3.7 \mathrm{mi}$.

Advance of glacial ice in the broad area between Schunemunk Mountain and the highest hills of the Hudson Highlands (fig. 2) resulted in the deposition of thick till aprons on slopes facing the ice advance and on some lee sides of low hills. As the glacial ice thinned and receded, meltwater from the ice in the low hills east of the Woodbury Creek valley would have drained toward the valley, and, as a consequence, this eastern area shows no indication of stratified drift suitable for water-resource use.

\section{Valley-Fill Deposits and Water-Resource Potential}

The valley fill in the north section reflects the presence of ice-dammed proglacial lakes in the presently north-draining Woodbury Creek valley. Lake plains in depressions amidst widespread thick till characterize the upper $2 \mathrm{mi}$ of the Woodbury Creek valley. Sand and gravel deposited during a pause in the ice retreat predominates in the valley reach between Highland Mills and the Woodbury Creek confluence with Mineral Spring Brook. North of this confluence, as far as Mountainville, fine-grained lacustrine deposits are the primary stratified deposit in the valley. In places, sand and gravel also was deposited in subglacial meltwater channels or lacustrine fans, over which lacustrine deposits or till were later deposited. North of Mountainville, within the low-relief Moodna Creek valley, stratified-drift deposits are very limited (fig. 2). The surrounding area is mostly covered by till, and sand and gravel occurs only in localized areas.

Five areas of aquifer material (identified by multiple well logs) are known to date (2013) along the Woodbury Creek and Moodna Creek valleys (fig. 2; plate 1). These sand and gravel deposits appear isolated from one another by either till and lacustrine deposits in the Mountainville and Central Valley areas or by pinchout of the aquifer where bedrock is exposed at land surface in the Woodbury Falls area. Three of the five areas are used for public supply or have been characterized for that eventual use. The valley-fill deposits in the Woodbury Creek valley are described below, from south to north.

The first area is immediately north of the midvalley divide between the Woodbury Creek and Ramapo River watersheds; ice-contact sand and gravel is mapped in surficial deposits near Peckman's Pond (plate 1; fig. 2). From the mapped sand and gravel, a thin aquifer is inferred to extend northward beneath fine-grained sediments. However, this valley reach, almost to Central Valley, is broad, flat, poorly drained, and likely was occupied by a downwasting ice block with little subsequent sediment deposition. This interpretation is supported by the difference in elevation of the valley floor on either side of the drainage divide; the valley floor in the 
headwaters of Woodbury Creek is nearly $30 \mathrm{ft}$ lower than the valley floor on the south side of the divide east of Harriman. Furthermore, there are no deep well or test-boring logs in this valley reach to verify the presence or thickness of an aquifer. Surficial sand and gravel is mapped from soils data along the west side of the valley, up to an elevation of $600 \mathrm{ft}$ above NAVD 88, but a passive seismic measurement implies that thin sand and gravel over till occurs in this area. Thus, the saturated thickness of the surficial sand and gravel is likely to be thin. Farther north at Central Valley, Woodbury Creek is narrowly incised through a mass of glacial drift that is identified as till by soils data, by a shallow test boring, and by field observation. Sand and gravel may be present beneath this till, but without further information, this locale is not inferred to include any aquifer material.

The second aquifer area extends about 1.7 mi north from Central Valley through Highland Mills nearly to Woodbury Falls (fig. 2). It is characterized by valley-bottom lacustrine deposits in much of the southern two-thirds of the area and by mostly ice-contact deposits, including a kame delta and an eskerform feature, in the northern one-third of the area. No stratified material is present on the east side of this area; however, along parts of the lower hillsides of the west side, thinly saturated ice-contact material is mapped up to elevations of $600 \mathrm{ft}$, as in the area just north of the Ramapo River-Woodbury Creek drainage divide (fig. 2; plate 1). Ice-contact sand and gravel is present beneath the lacustrine deposits and is hydraulically connected with the near-surface ice-contact deposits to the north (Frimpter, 1972; p. 45-47). The village of Woodbury draws much of its water supply from this aquifer area.

The third aquifer area extends from Woodbury Falls about $2.5 \mathrm{mi}$ north, nearly to Mountainville. For about 1 mi north of Woodbury Falls to the Mineral Spring Brook confluence, the valley contains unconfined sand and gravel and the lower valley sides are mantled by thinly saturated sand and gravel deposited by south-flowing meltwater alongside an ice tongue in midvalley. Between Mineral Spring Brook and Mountainville, lacustrine clay, silt, and fine sand accumulated in the valley. Parts of the valley floor were later mantled by masses of till that apparently slid as landslides from the steep valley walls. In the northern $1.5 \mathrm{mi}$ of this aquifer area, sand and gravel deposited by earlier south-flowing meltwater (within and beneath the ice) locally occurs on top of bedrock, beneath fine-grained lacustrine deposits or till (fig. 2; plate 1).

Aquifer tests have been performed on at least six wells within the third aquifer area, but currently (2013), none are being used for water supply. Yields between 30 and $400 \mathrm{gal} / \mathrm{min}$ have been reported (Leggette, Brashears, and Graham, Inc., 2007, 2011; S. Gagnon, Orange County Department of Health, written commun., 2011). The maximum northern extent of this aquifer area is indicated by five test borings across the valley that show no aquifer material except for $2 \mathrm{ft}$ of sand and gravel in one test boring (wells O1957-61, plate 1, appendix 1; Hazen and Sawyer, 1963; see also geologic section $B-B^{\prime}$ in Frimpter, 1972).
Near Mountainville, the north end of Woodbury Creek valley is choked with thick accumulations of till on the valley flanks and beneath the valley floor (fig. 6 at back of report). The fourth aquifer area is defined by several well records showing that the till on the east side of the valley buries and confines an older sand and gravel deposit (fig. 2, fig. 6 at back of report; plate 1).

A fifth aquifer area, similarly confined beneath till and also lacustrine clay, is present along Moodna Creek about $1.5 \mathrm{mi}$ northwest of Mountainville (plate 1). This aquifer is limited in areal extent, but productive. The eastern part of the aquifer area is tapped by domestic wells, whereas the western part is tapped for municipal supply by wells capable of yielding 300-350 gal/min (S. Gagnon, Orange County Department of Health, written commun., 2011).

Beyond these locales, till is the predominant surficial deposit north of Moodna Creek. Available well log data indicate that other mapped ice-contact deposits in this area mostly overlie till and likely are thinly saturated. Additional subsurface data are needed to verify this, as there are indications of saturated sand and gravel at two isolated locations north of Mountainville (fig. 2; plate 1).

\section{Groundwater Circulation}

Groundwater circulation in the study area includes movement through both fractured bedrock and stratifieddrift aquifers. The ultimate source of water across the area is the infiltration of precipitation (recharge) at land surface. Recharge occurs over most land area where surficial deposits or bedrock are permeable enough to allow infiltration, except for those areas where groundwater typically discharges under natural conditions, such as most lakes, streams, and wetlands. Most groundwater circulation in upland areas is through fractured bedrock, is predominantly downslope, and occurs through the upper 100-300 ft of bedrock. A small amount of groundwater moves more slowly downward into deeper bedrock. If till in the uplands is permeable, particularly in areas of metamorphic rock, groundwater flow through these otherwise low-permeability deposits may also be important. This upland groundwater (in till and bedrock) moves downslope to valley areas unless it is first discharged to upland streams and wetlands or taken up by vegetation (evapotranspiration). Downslope movement of groundwater to valleys is controlled by bedrock structure and fracture permeability and is, therefore, not necessarily directly downslope.

Shallow hillslope groundwater likely will flow into the shallowest valley-fill deposits and toward the stream or discharge to land surface at springs if the shallow valleyfill deposits are not permeable. Precipitation that falls and infiltrates directly to unconfined aquifers on the valley bottom also will flow toward the stream. Natural shallow groundwater flow in valleys toward the stream will have a downvalley 
component, dependent on the valley gradient and geometry. Where tributary streams enter valleys across alluvial fans, they commonly lose flow as water in the stream infiltrates into the streambed (Randall, 1978) and replenishes the aquifer, if subsurface deposits are permeable.

Deeper groundwater flow from hillsides either moves into deep valley-fill deposits or maintains hydrostatic pressure in those deposits and is forced upward to discharge into shallower aquifer material. Increasing hydrostatic pressure with depth in valleys, whether the aquifer materials are confined or not, results in high groundwater levels (near or above land surface; levels above land surface result in flowing conditions) in deep valley wells under nonstressed conditions.

The midvalley surface-water divide between the Ramapo River and Woodbury Creek appears to be a groundwater divide as well. Few well logs in the immediate area of the divide imply till down to bedrock; however, subsurface pathways for groundwater movement across the divide, such as deep permeable sediments overlying a fault zone, could be present.

\section{Water-Resource Considerations for the Valley-Fill Aquifer System}

Groundwater resources within the valley-fill aquifer system are constrained by the discontinuous nature and limited thickness of saturated sand and gravel and by the relatively small size of streams in the area. Supply wells and test wells have been completed in many of the more extensive or relatively thick valley-fill deposits. Several areas with little subsurface data were noted within the study area that may have additional water-resource potential:

1. The valley area between the midvalley divide and Central Valley appears largely unexplored-ice-contact deposits at Peckman's Pond may extend northward beneath finegrained alluvium and, most likely, lacustrine deposits.

2. A side valley that trends northeast from Central Valley east of linear hill A (figs. $1 B$ and 2) is drained by a tributary of Mineral Spring Brook. This valley may have previously been a substantial drainage path prior to deposition of thick till that blocks its south end and, if so, it may have some permeable sediment at depth. 3 .

3. Ice-contact deposits mapped north of Moodna Creek, at the northernmost extent of the study area, may have water-resource potential. Well logs from the west side of this deposit indicate thinly saturated sand and gravel over till. A few logs near the southern end of the Storm King Art Center (fig. 1A) describe thick sand and gravel but well $\log$ verification and locations were not definitive.
4. The Ramapo River valley reach from Southfields to where the Ramapo River departs from the main fault valley is intersected by several fault- or lineament-based tributary valleys, which imply favorable aquifer conditions.

5. Last, former meltwater channels identified south of Schunemunk Mountain on plate 1 have modest potential in reaches where the channel slopes were low and sediment infilling occurred. Sand and gravel beneath fine grained sediments has been identified and used for domestic supply and modest public supply (Leggette, Brashears, and Graham, Inc., 1987). Several of these areas are occupied by lakes and wetlands.

Considerations other than the limited areal extent and thickness of aquifer sediments also may place constraints on the use of groundwater resources in the study area. Contamination from human activities could potentially affect the quality of the groundwater, limiting its use for drinking water or other purposes. For example, infiltration of runoff contaminated by road salt can adversely affect groundwater quality; all valleys contain at least one major highway and the narrow valley of the south section contains two - the New York State Thruway (Interstate 87) and Route 17 (Interstate 86). A supply well in a valley such as this would most likely divert shallow salt-affected water to the well that would have otherwise discharged to the valley stream. Other large areas of impervious surface may also contribute runoff with high dissolved solids to groundwater. Infiltration of fertilizers or pesticides in runoff from developed areas such as golf courses or residential lawns are another source of contamination that might affect groundwater quality in unconfined aquifers. Constraints on the use of the stratifieddrift aquifers also could arise because of a need to limit the effects of groundwater withdrawals on streamflows through induced infiltration, especially during summer low-flow periods when water demand is high.

Several types of monitoring could provide useful information for further evaluation of the groundwater resources in the study area. Measurement of the rate(s) at which streamflows may be reduced by present-day groundwater withdrawals from nearby shallow, high-capacity wells, especially during summer low-flow periods when water demand is high, could provide useful information for evaluating the effects of withdrawals on streamflows. As the number of active production wells increases, especially in confined aquifer areas, long-term continuous groundwaterlevel measurements at dedicated monitoring wells between groups of production wells within and among aquifer areas would (1) provide an indication of the degree of hydraulic interconnection within the valley-fill aquifer system and (2) provide the context needed to evaluate the effects of seasonal and long-term pumping stresses on the aquifer system that can alert water managers to downward water-level trends that might indicate nonsustainable use of water resources. 


\section{Summary}

The Woodbury Creek-Ramapo River valley-fill aquifer system and associated water resources in eastern Orange County, New York, were investigated in cooperation with the New York State Department of Environmental Conservation. The aquifer system was delineated and characterized based on surficial deposits and landforms, subsurface information, and previous work in the area. An interactive map depicts the aquifer extent and thickness, surficial geology, and approximate bedrock elevation beneath valleys over base maps of shaded relief light detection and ranging (lidar) imagery and 1:24,000 scale topographic maps. An appendix of well data is also provided. The study area was divided into three sections for ease of discussion.

The south section is the south-draining part of the Ramapo River watershed where the river follows a narrow, fault-controlled valley. This section is primarily underlain by resistant metamorphic bedrock of the Hudson Highlands. Little available well-log data indicate that fine-grained deposits likely predominate within the valley fill, except (1) at and immediately south of Arden; (2) potentially at valley junctions with major tributary streams where influxes of coarse-grained sediments may have occurred, such as at, and south of, Southfields; and (3) where the valley broadens near Harriman and extensive coarse sand and gravel occurs. Lineaments that cross the valley may convey some additional water from upland areas.

The central section is the headwater watershed of the Ramapo River, including the villages of Monroe and Harriman. The low-relief, west-east valley is characterized by typically thin outwash sand and gravel deposits of limited areal extent that overlie till. High-capacity wells in shallow unconfined aquifer zones likely require induced infiltration of surface water to maintain well yield.

The north section has the greatest water-resource potential from valley-fill deposits, as indicated by well logs, present-day (2013) water use, and previously conducted aquifer tests. However, the valley-fill aquifers are discontinuous in several parts of this section: (1) near Woodbury Falls, where bedrock is exposed in the streambed; (2) south of Mountainville, where little or no gravel was penetrated by several wells and test borings; and (3) perhaps also at Central Valley, where till is mapped all across the valley. Both shallow unconfined and deeper confined aquifer zones have been identified. However, until pumping stresses are applied to the aquifer system and groundwater-level responses are monitored, the degree of hydraulic connection among aquifer areas and between the aquifers and surface water will remain largely unknown, as will the potential productivity of the aquifer system. Further exploration in the north section (as well as in parts of other sections) also may identify areas of aquifer material that are not apparent because of a lack of subsurface information.

\section{References Cited}

Cadwell, D.H., ed., 1989, Surficial geologic map of New York, Lower Hudson sheet: New York State Museum and Science Service, Map and Chart Series no. 40, scale 1:250,000.

Coates, D.R., 1966, Glaciated Appalachian Plateau-Till shadows on hills: Science, v. 152, p. 1617-1619.

Connally, G.G., and Sirkin, L.A., 1967, The Pleistocene geology of the Wallkill Valley, in Waines, R.H., ed., New York State Geological Association Guidebook, 39th annual meeting: State University of New York College, New Paltz, N.Y., p. A1-A21.

Connally, G.G., Sirkin, L.A., and Cadwell, D.H., 1989, Deglacial history and environments of the upper Wallkill Valley, in Weiss, Dennis, ed., New York State Geological Association Guidebook, 61st annual meeting, October 13-15, 1989: Orange County Community College, Middletown, New York, p. 205-230.

Dodd, R.T., 1965, Precambrian Geology of the Popolopen Lake Quadrangle, southeastern New York: New York State Museum and Science Service, Map and Chart Series no. 6, 39 p., 1 plate.

Epstein, J.B., 1993, Stratigraphy of Silurian Rocks in Schawangunk Mountain, southeastern New York, including a historical review of nomenclature-A description and partial revision of the physical stratigraphy: U.S. Geological Survey Bulletin 1839-L, 40 p.

Fisher, D.W., Isachsen, Y.W., and Rickard, L.V., 1970, Geologic map of New York, Lower Hudson sheet: New York State Museum and Science Service, Map and Chart Series no. 15, scale 1:250,000.

Frimpter, M.H., 1970, Ground-water basic data, Orange and Ulster Counties, New York: New York State Department of Environmental Conservation, Water Resources Commission Bulletin 65, $93 \mathrm{p}$.

Frimpter, M.H., 1972, Ground-water resources of Orange and Ulster Counties, New York: U.S. Geological Survey WaterSupply Paper 1985, 80 p.

Gates, A.E., and Valentino, D.W., 2000, Geologic map of the Monroe 7.5 minute quadrangle, New York; New York State Geological Survey Open-File Report no. 1 g1436.

Gates, A.E., Valentino, D.W., Chiarenzelli, J., and Volkert, R.A., 2001, Geologic map of the Sloatsburg 7.5 minute quadrangle, New York; New York State Geological Survey Open-File Report no. 1g1437. 
Hazen and Sawyer Engineers, 1963, Exploratory and test well program May-December 1963, Village of Cornwall, N.Y., unpaged, 1 plate, scale 1:24,000.

Isachsen, Y.W., Landing, E., Lauber, J.M., Richard, L.V., and Rogers, W.B., eds., 2000, Geology of New York-A simplified account (2d ed.): New York State Museum Educational Leaflet 28, 294 p.

Isachsen,Y.W., and McKendree, W.G., 1977, Preliminary brittle structure map of New York-Niagara-Finger Lakes sheet: New York State Museum Map and Chart Series no. 31D, scale 1:250,000.

Jaffee, H.W. and Jaffee, E.B., 1973, Bedrock geology of the Monroe Quadrangle, Orange County, New York: New York State Museum and Science Service, Map and Chart Series no. 20,67 p., 1 plate.

Lane, J.W., Jr., White, E.A., Steele, G.V., and Cannia, J.C., 2008, Estimation of bedrock depth using the horizontalto-vertical (H/V) ambient-noise seismic method, in Symposium on the application of geophysics to engineering and environmental problems, April 6-10, 2008, Philadelphia, Pennsylvania, Proceedings: Denver, Colo., Environmental and Engineering Geophysical Society, 13 p.

Leggette, Brashears, and Graham, Inc., 1987, Hydrogeologic evaluation of the Highland Lake Estates, Town of Woodbury, New York: Report for Carl Mays, Corkill and Seddon, Inc., variously paged.

Leggette, Brashears, and Graham, Inc., 1994, Ground-water resources of Orange County, New York: Report for Orange County Water Authority, N.Y.,variously paged.

Leggette, Brashears, and Graham, Inc., 1997, Well completion report, Village of Monroe, ground-water exploration program: Report for Village of Monroe, N.Y., variously paged.

Leggette, Brashears, and Graham, Inc., 1999, Well completion report, Village of Monroe, ground-water exploration program: Report for Village of Monroe, N.Y., variously paged.

Leggette, Brashears, and Graham, Inc., 2007, Ground-water exploration program, Legacy Ridge, Town of Woodbury, N.Y.: Report for Legacy Ridge, variously paged.

Leggette, Brashears, and Graham, Inc. 2011, 72-hour pumping test report for well 1, Mountainville pump station parcel, Route 32, Cornwall, New York: Report for Village of Kiryas Joel, N.Y., variously paged.
McNamara, I., Cirmo, A., and Gates, A.E., 2008, Geologic map of the Cornwall 7.5 minute quadrangle, New York: New York State Geological Survey Open-File Report 2508.

Orange County Department of Planning, 2014, Population change 2000-2010: Goshen, N.Y., accessed March 3, 2014, at http://www.orangecountygov.com/ filestorage/124/1362/3210/Population_Change_2000-2010. $p d f$.

Randall, A.D., 1978, Infiltration from tributary streams in the Susquehanna River Basin: U.S. Geological Survey Journal of Research, v. 6, no. 3, p. 285-297.

Rickard, L.V., 1975, Correlation of Silurian and Devonian rocks in New York State: New York State Museum and Science Service, Map and Chart Series no. 24, 16 p.

Stanford, S.D., 1992, Surficial geology of the Greenwood Lake and Sloatsburg quadrangles, Passaic, Bergen, and Sussex Counties, New Jersey: New Jersey Geological and Water Survey, Open File Map 6, scale 1:24,000.

Stanford, S.D., 2004, Surficial geology of the Ramsey quadrangle, Bergen and Passaic Counties, New Jersey: New Jersey Geological and Water Survey, Open File Map 62, scale 1:24,000.

U.S. Department of Agriculture, 2011, Soil survey geographic (SSURGO) database for Orange County, New York, accessed October 30, 2011, at http://soildatamart.nrcs.usda. gov/.

U.S. Environmental Protection Agency, [n.d.], Safe drinking water information system (SDWIS) database, accessed July 14, 2010, at http://oaspub.epa.gov/enviro/sdw_form $v 2$.create_page? state_abbr $=N Y$.

U.S. Geological Survey, 2012, National water information system (NWISWeb), accessed October 5, 2012, at http:// waterdata.usgs.gov/nwis/.

Valentino, D.W., Pagano, W. and Gates, A.E., 2004, Geologic map of the Popolopen Lake 7.5 minute quadrangle, New York: New York State Geological Survey Open-File Report 2505 .

Witte, R.W., 2011, Surficial geologic map of the New Jersey part of Unionville quadrangle, Sussex County, New Jersey: New Jersey Geological and Water Survey, Open File Map 82, 13 p., scale 1:24,000. 
Figures 3 through 6 


\section{EXPLANATION FOR FIGURES 3-6}

(figures 3-6, location of cross sections shown on plate 1, http://pubs.usgs.gov/sir/2014/5156/

03751<smiles>CCCCCCCCCCCC</smiles>

01405

Alluvium-Postglacial river and stream flood-plain deposits consisting predominantly of stratified silt and clean to silty sand, commonly with some gravel at the base of the deposit. Alluvium generally occurs within $10 \mathrm{feet}(\mathrm{ft})$ of the present-day stream or river level. Thickness is as much as 15 to $25 \mathrm{ft}$.

Alluvial fan-Fan-shaped accumulations of stratified silty sand and gravel, deposited by tributary streams where they enter the Ramapo River-Woodbury Creek valleys. Maximum thickness of fans may approach $40 \mathrm{ft}$, but is likely less than $20 \mathrm{ft}$ for most fans Alluvial fan deposits have relatively high permeability, but are relatively thin and largely unsaturated. Fan deposits are an important conduit for groundwater recharge if the underlying glacial deposits are permeable. Most fans in the northern half of the study area overlie fine-grained deposits that limit recharge

Artificial fill—Road and railroad embankments and landfills

Open water-Areas of open water such as streams, rivers, lakes, large ponds, and reservoirs

Outwash sand and gravel-Stratified, well-sorted sand and gravel deposited by glacial meltwater streams away from the ice front as valley-train outwash (originally spanning the width of the valley). Outwash terraces or topset beds of deltas near the receding ice front also are included. Outwash in the Ramapo River-Woodbury Creek valley is largely limited to the southward draining Ramapo River section. Outwash deposits are delineated within the short west to east section of the Ramapo River and from Arden downvalley to the south. Upper surfaces generally 20 to $60 \mathrm{ft}$ above river level, except at the head of the outwash near Arden, where the valley is constricted and incision approaches $70 \mathrm{ft}$. Outwash sand and gravel deposits have very high permeability, but somewhat limited aquifer potential because of thin saturated thicknesses

Ice-contact sand and gravel-Undifferentiated ice-contact deposits of poor- to well-sorted sand and gravel with variable amount of silt that was deposited adjacent to, or beneath, within, or on top of melting glacial ice. Includes geomorphic features such as kames, kame terraces, kame deltas, eskers, and permeable hummocky terrain mostly within valleys. Coarse stratified deposits in the subsurface likely originated from subglacial drainage or subaqueous or lacustrine fans, deposited where meltwater discharged into proglacial lakes. Extreme variability in sorting, grain size, and thickness of individual beds. Moderate to high permeability, high permeability especially in coarse, well-sorted zones. Deposits situated at low altitude (below the valley floor) and with favorable characteristics (high permeability) form localized unconfined or confined aquifers

Lacustrine silt and clay or sand-Glaciolacustrine deposits of thinly to massively bedded silt, fine to very fine sand, and some clay. Deposited as lake-bottom sediments in proglacial lakes that formed as a result of the temporary dams created by ice, till moraines, or downvalley ice-marginal deposits such as high-outwash valley trains and kame moraine and kame delta deposits. Thicknesses can reach as much as $150 \mathrm{ft}$. These deposits have low permeability and form the principal confining unit in the Ramapo River-Woodbury Creek valley-fill aquifer system

Till-Unsorted, unstratified mixture of clay, silt, sand, gravel, and boulders deposited beneath the ice as lodgment till during a glacial advance or at the edge of the ice sheet by melting ice as ablation till during a pause, or retreat, of the ice front. Very low permeability, but may yield adequate amounts of water for domestic use to large-diameter dug wells where sufficiently saturated or where gravelly zones of higher permeability exist

Bedrock - Description from drillers' well logs. If rock type is not indicated in well logs, " $r$ " is used. If rock type is indicated, an abbreviation in parentheses follows. Abbreviations are as follows: Ss., sandstone; Sh., shale; Ls., limestone; Gran., granite. "Gneiss" is not abbreviated

Horizontal-to-vertical (H/V) passive seismic survey site-Dashed line indicates estimated depth to bedrock. "no estimate" indicates that a measurement was made but site conditions prevented estimation of overburden thickness

Well-Label is well identification number assigned by the U. S. Geological Survey (USGS). Horizontal line and text indicates reported depth to groundwater from top of casing (from drillers' well log) 


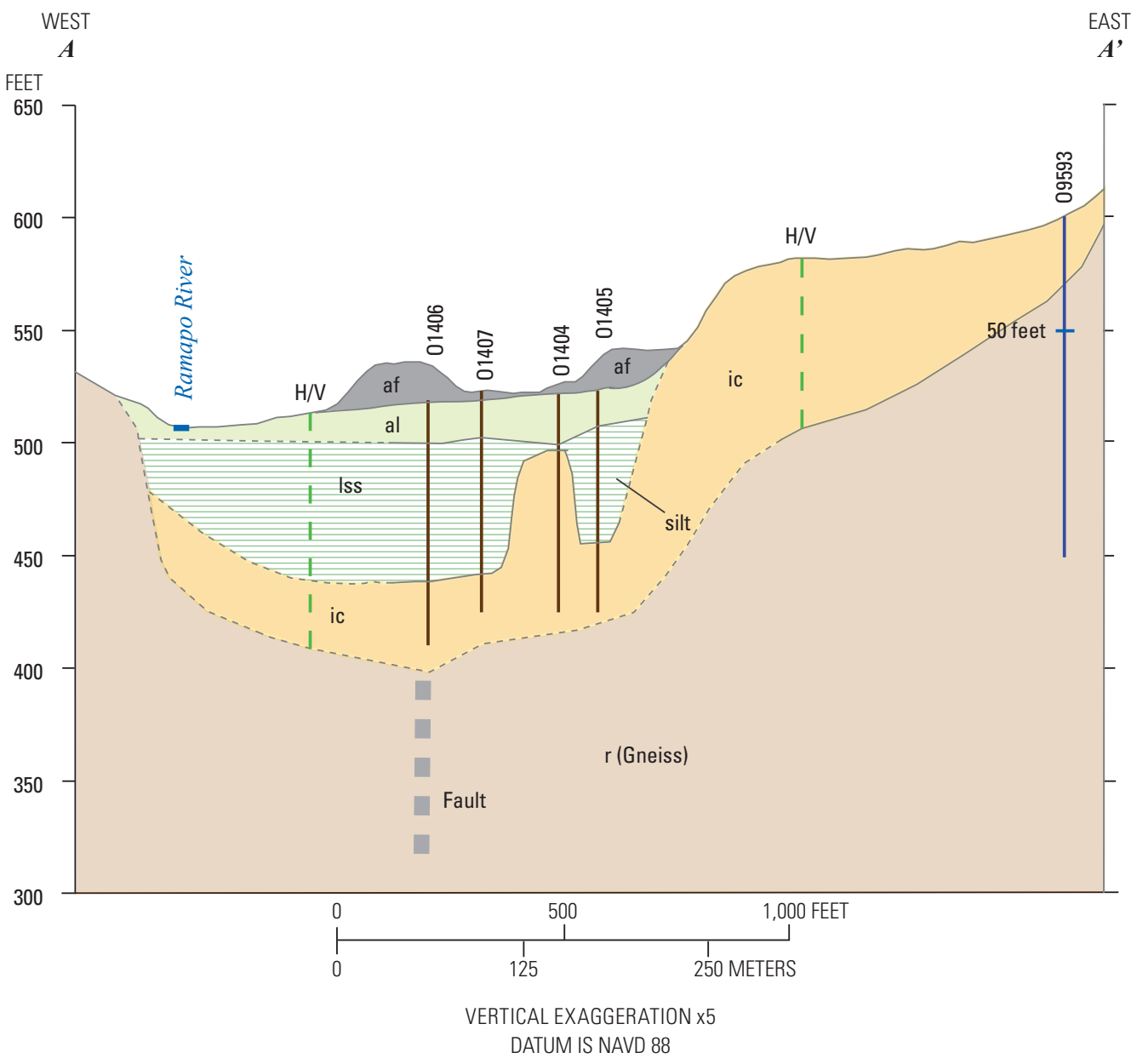

Figure 3. Hydrogeologic section $A-A^{\prime}$ at Arden, Orange County, New York. 


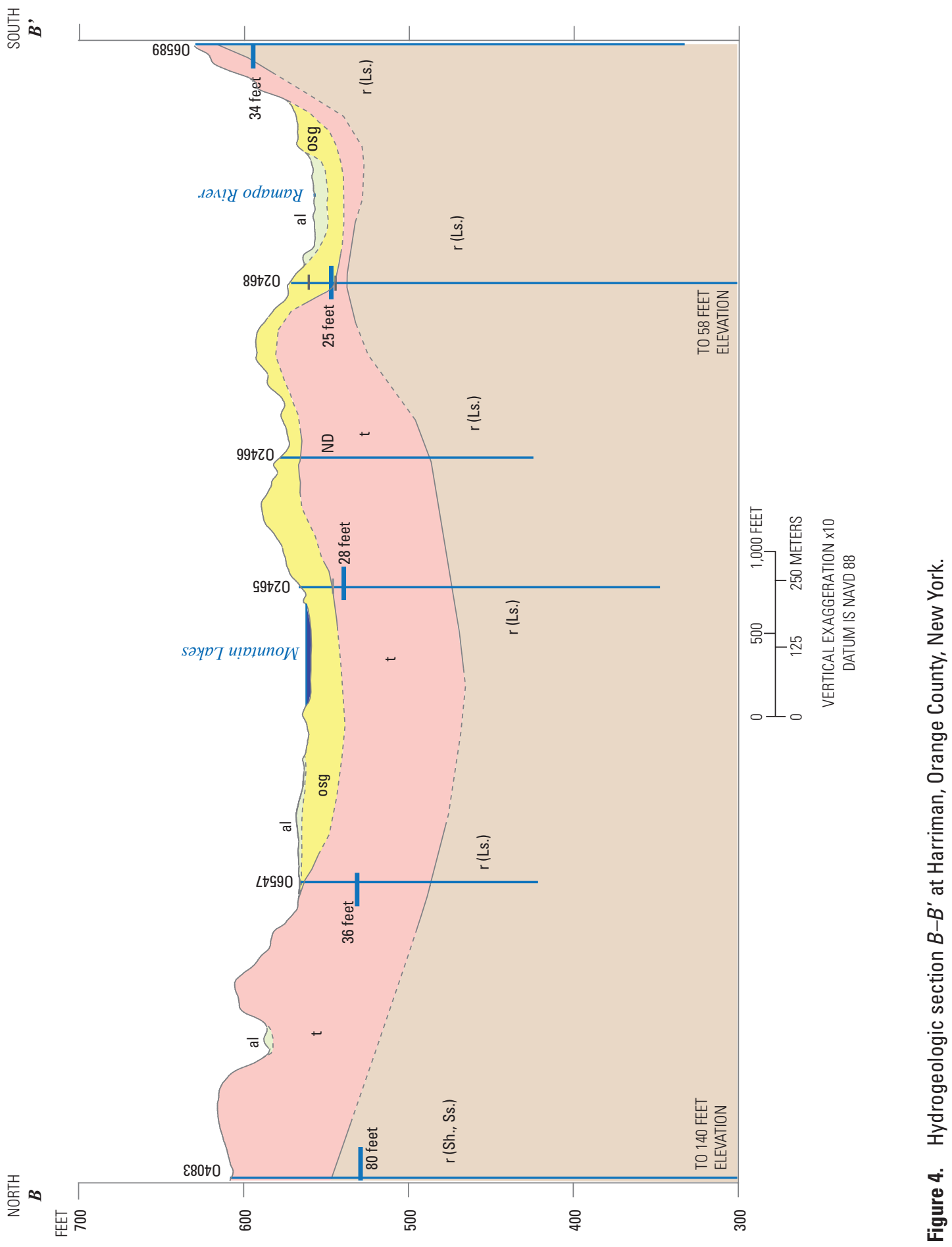




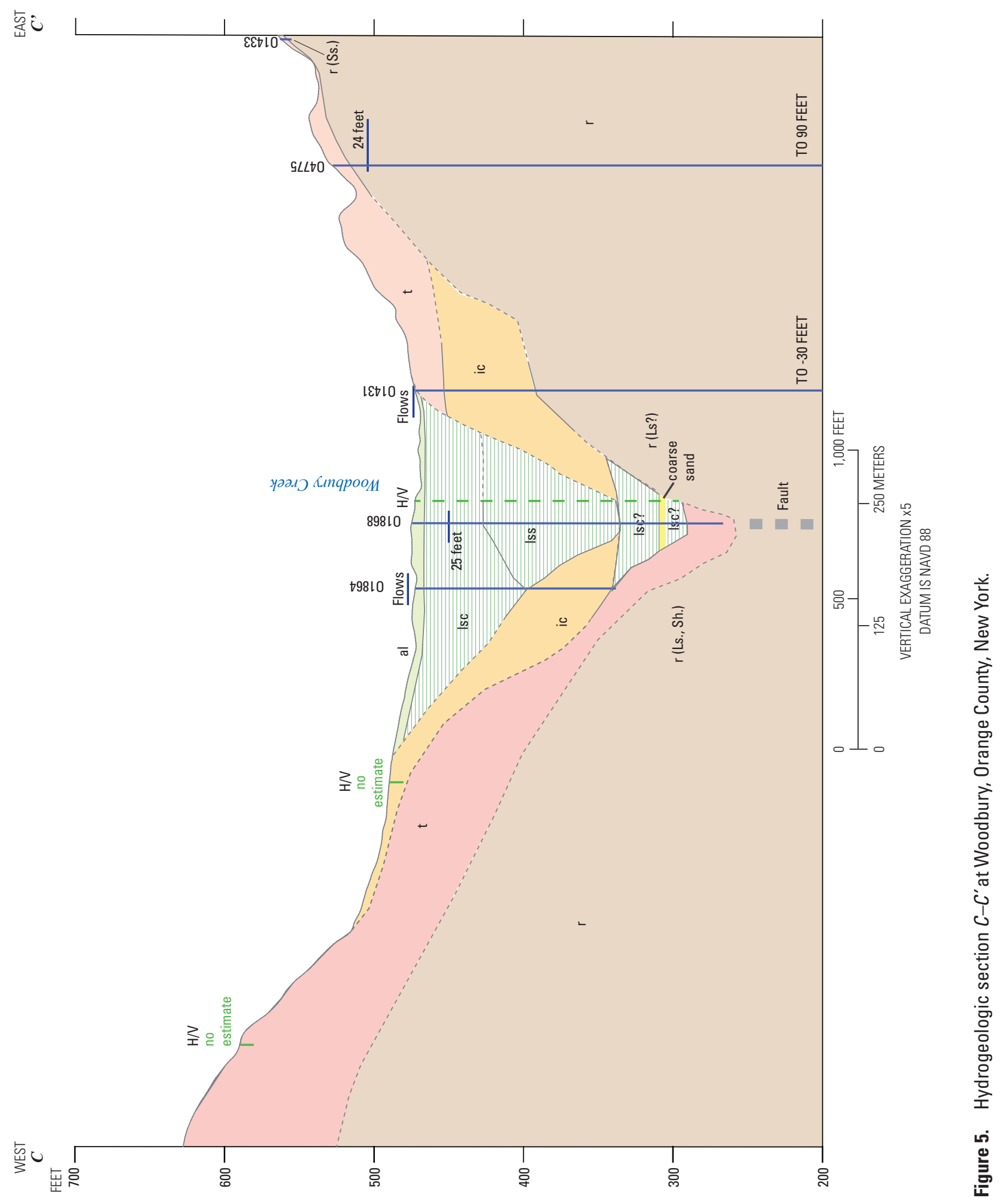




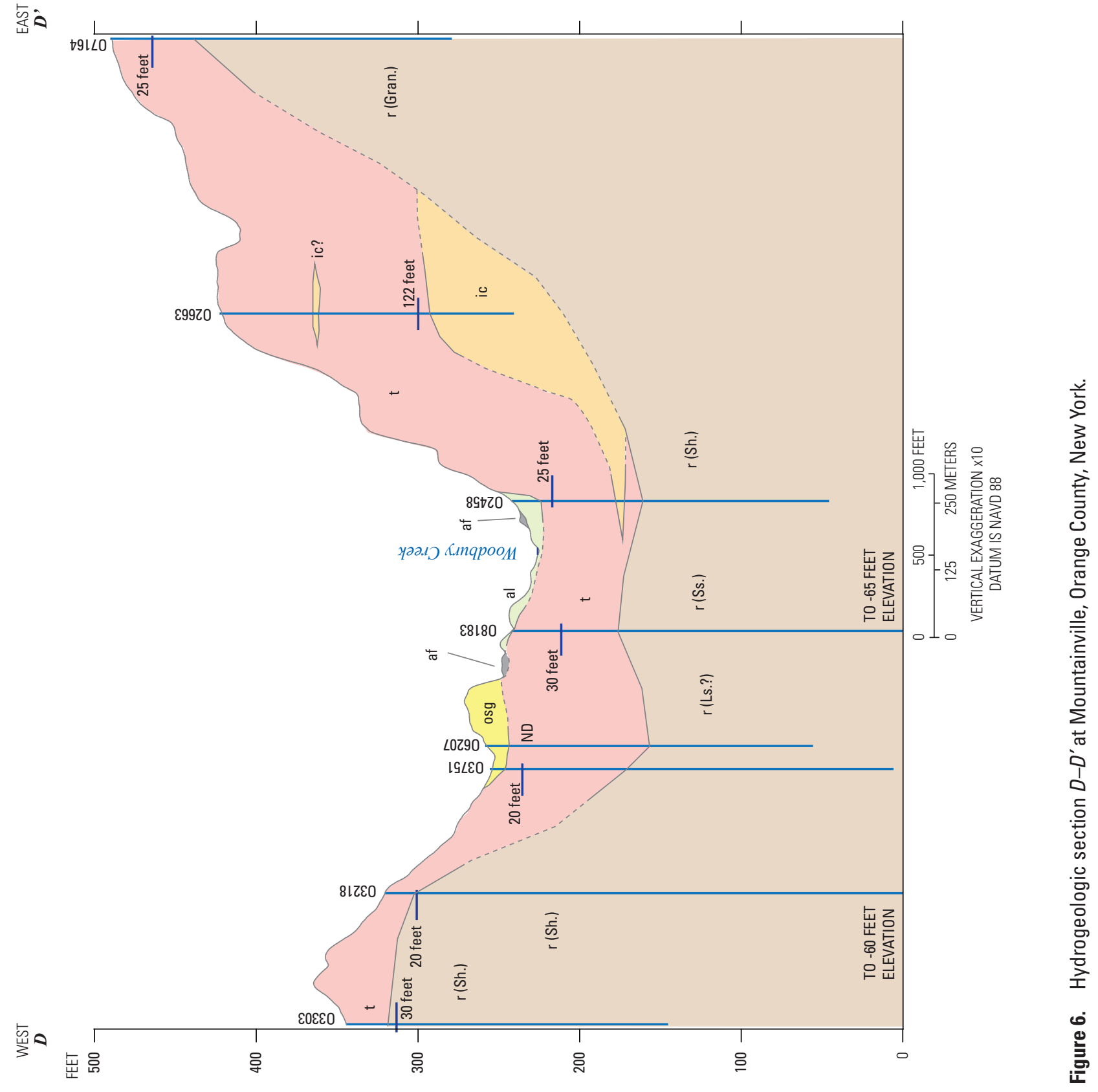


Appendixes 1-2 
Appendix 1. Well Data for the Ramapo River-Woodbury Creek Valley and Adjacent Uplands, Eastern Orange County, New York (http://dx.doi.org/10.3133/ sir20145156) 






Publishing support provided by the Pembroke and Rolla Publishing Service Centers.

For more information concerning this report, contact:

Director

New York Water Science Center

U.S. Geological Survey

425 Jordan Road

Troy, NY 12180-8349

dc_ny@usgs.gov

or visit our Web site at:

http://ny.water.usgs.gov 


\section{迹}

